\title{
Sikap Media Daring Dalam Kontestasi Pilkada DKI 2017 (Analisis terhadap Sikap Media Daring dalam Isu Dugaan Penghinaan Kitab Suci Al-Qur'an oleh Cagub Ahok dalam Rentang Pemberitaan 5 Oktober S.D. 20 Oktober 2016)
}

\author{
Anggalih Bayu Muh.Kamim \\ Mahasiswa Departemen Politik dan Pemerintahan, Fakultas Ilmu Sosial dan Ilmu Politik, \\ Universitas Gadjah Mada, Kode Pos 55281. \\ Email : anggalih.bayu@yahoo.co.id
}

\begin{abstract}
Abstrak
Media daring menjadi salah satu wahana bagi proses pendidikan politik dan tantangan literasi terkait dengan ikhwal pilkada serentak. Pilkada serentak yang akan berlangsung salah satunya di provinsi DKI Jakarta pada tahun 2017 diikuti dengan berbagai intrik salah satunya adalah kasus dugaan penghinaan kitab suci Al-Qur'an oleh Cagub Ahok. Media termasuk media online cukup masif memberitakan isu tersebut dengan berbagai pendekatan. Penyikapan berbagai media online terkait isu penghinaan kitab suci Al-Qur'an oleh Cagub Ahok memperlihatkan karakteristik yang berbeda dari media online terkait. Dengan menggunakan teknik analisis isi, riset didasarkan pada 4 poin yang dilihat yaitu intensitas peliputan, pemilihan narasumber, fokus pemberitaan, dan tendensi sikap media. Hasil penelitian menunjukan sikap media yang diteliti yakni Kompas.com, Merdeka.com, Detik.com memiliki karakteristik yang berbeda-beda terhadap pemberitaan isu dugaan penghinaan Kitab Suci Al-Qur'an oleh Cagub Ahok. Karakteristik yang berbeda menunjukan sejauhmana tantangan literasi yang muncul dalam pemberitaan media online terhadap isu terkait. Media Online ternyata memiliki sudut pandang yang berbeda dalam memberitakan dugaan penghinaan Kitab Suci Al-Qur'an oleh Cagub Ahok.
\end{abstract}

\section{Kata Kunci : Media Online, Cagub Ahok, Karakteristik, Tantangan Literasi}

\begin{abstract}
Online media into one vehicle for the political education and literacy challenges related to matters of election simultaneously. Simultaneous local elections which will take place one of them in the province of Jakarta in 2017, followed by various intrigues one of them is the alleged insult the holy book of the Qur'an by Cagub Ahok. Sufficiently massive online media to report on the various approaches. Attitudinal issues related to various online media insult the holy book of the Qur'an by Cagub Ahok show different characteristics of the online media-related. Using the content analysis technique, the research is based on 4 points is seen that the intensity of the coverage, the selection of the source, the focus of the news, and mainstream media attitude. The results showed that the attitude of the media studied Kompas.com, Merdeka.com, Detik.com have different characteristics to the preaching of the issue of the alleged insult the Scriptures of the Qur'an by Cagub Ahok. Different characteristics indicate the extent of the challenge of literacy in the news media online on related issues. Online Media proved to have a different point in reporting the alleged insult the Scriptures of the Qur'an by Cagub Ahok.
\end{abstract}

Keywords: Online Media, Cagub Ahok, Characteristics, Challenges Literacy 


\section{Pendahuluan}

Pemilu merupakan sarana kehidupan politik negara demokrasi modern yang tida terpisahkan. Bagi bangsa yang tengah berjuang melembagakan "kekuasaan rakyat", menurut Indonesianis, Lance Castles, pemilu masih dihayati sebagai "ritus massal." Suatu perayaan kebersamaan, yang bisa gagal atau mengecewakan, tapi juga bisa menjadi langkah maju dalam melembagakan kedaulatan rakyat secara efektif dan lestari.

Pemilu memang merupakan keputusan yang sangat penting bagi masa depan negara. Bila suatu pemilu berjalan baik, maka sebuah negara dapat melanjutkan menuju demokrasi dan perdamaian. Sebaliknya, bila pemilunya berjalan buruk bahkan gagal, sebuah negara bisa kembali menuju titik nadirnya. Itulah sebabnya pemilu kerap disebut sebagai "roh" demokrasi.

Pemilu bagi reporter politik laksana olimpiade bagi reporter olah raga. Seperti olimpiade, kata analis media dan pemilu Denish Kavanagh, pemilu dipandang sebagai peristiwa penting dalam politik. Tak mengherankan, bila media tidak mau ketinggalan dalam meliput pemilu, yang dulu sering disebut sebagai "pesta demokrasi” (Suranto, dkk, 2008: 3-5). Dalam konteks ini, peran media yang independen dalam menyediakan informasi merupakan faktor pendukung bagi suksesnya demokrasi di Indonesia. Karena itu, terlepas eksistensi media sosial yang lebih fleksibel dalam menyebarkan informasi, media massa ataupun media mainstream tetap memiliki kekuatan sebagai rujukan informasi masyarakat. Berdasarkan gambaran tersebut, yang diperlukan oleh masyarakat. Demokrasi dan pemerintahan yang baik akan sangat bergantung pada keberadaan media massa yang tidak dipengaruhi oleh berbagai kekuatan sosial, ekonomi maupun politik, dan lebih mengedepankan kualitas informasi kepada khalayak. Namun yang menjadi pertanyaan, sejauhmana media massa di Indonesia dapat bersikap independen dan lepas dari pengaruh pemerintah? Tidak bisa diabaikan, bahwa budaya kekuasaan paternalistik dan karakteristik tradisional yang cenderung menutup diri, masih melembaga dan berpotensi menghambat kebebasan pers (Susanto, $2014:$ 5-7).

Pemilu memang kerap dipandang sebagai momen di mana nasib bangsa ditentukan, setidaknya untuk lima tahun ke depan. Sebagai arena pertarungan resmi dalam ritual demokrasi, pemilu menjadi momen di mana berbagai gagasan, citacita, dan harapan ditawarkan, diperdebatkan, dan lantas diputuskan. Media, tentu saja, merupakan ruang yang penting bagi berlangsungnya pasar gagasan tersebut. Karena itu, media harus menjadi 'ruang publik' yang memungkinkan segenap warga negara 
mendialogkan berbagai gagasan dan kemudian memutuskannya. Termasuk dalam ini, kontestasi Pilkada DKI 2017.

Pilkada DKI 2017 dapat dikatakan sebagai barometer penyelenggaraan pilkada secara nasional. Kedudukan Jakarta sebagai ibukota negara menjadikan posisinya dalam kancah pilkada akan menunjukan sejauh mana proses suksesi dalam demokrasi elektoral tercapai. Pilkada DKI menjadi ramai dalam liputan media, termasuk media online yang gencar memberitakan masalah Pilkada DKI, mulai dari kandidat yang muncul dan lain-lain. Salah satu isu yang kuat adalah persoalan SARA, yang digencarkan karena kasus dugaan Petahana Ahok menghina kitab suci AlQur'an.

Sifat kampanye di media sosial dapat dikatakan berkebalikan dengan kampanye di dunia nyata. Jika di dunia nyata kampanye begitu "berisik," keras suaranya tapi tanpa bukti nyata, maka di media sosial adalah kampanye "penuh makna." Setiap suara punya arti, memiliki pembuktiannya sendiri-sendiri. Politik di media sosial bisa merupakan politik sejati, yaitu politik yang benar-benar berisi ideide dan aksi nyata untuk kebaikan umum. Inilah politik yang memiliki daya dobrak. Berbagai isu sosial yang menjadi beban masyarakat sering kali mendapatkan solusinya di media sosial.

Dalam menyiarkan berita pilkada, media online selalu menempatkan framing tertentu. Ini dilakukan untuk menggiring pada suatu opini publik tertentu. Oleh karena itu, masyarakat dituntut kemampuan literasinya dalam menghadapi terpaan media yang sangat kuat, termasuk isu dugaan penghinaan ayat kitab suci Al-Qur'an dalam Pilkada DKI. Oleh sebab itu, dalam kajian ini, penulis tertarik untuk menganalisis sikap media online dalam memberitakan isu Petahana Ahok yang diduga menghina kitab suci Al-Qur'an yang akan berimplikasi pada suksesi Pilkada DKI 2017. Media online yang dianalisis dalam kajian ini adalah Kompas.com, Detik.com, dan Merdeka.com pada masa pemberitaan 5 Oktober s.d. 20 Oktober 2016. Media massa memiliki peran-peran tertentu selama periode pemilu termasuk juga selama periode kampanye. Dalam hubungan ini, peran-peran yang dimaksud mencakup dua sisi sekaligus, yakni, pada satu sisi, media massa digunakan oleh partai politik, elite politik, para calon, para kader dan simpatisan untuk kepentingan kampanye dengan tujuan akhir memperoleh dukungan suara; dan, pada sisi lain, media massa juga digunakan oleh publik (warga masyarakat calon pemilih) dengan intensitas, pola, motif yang beragam sebagai bentuk partisipasi politik yang, sampai tingkat tertentu setidaknya, boleh jadi mempengaruhi pendapat, sikap, serta keputusan-keputusannya dalam menentukan pilihan/dukungan (Pawito, $2011: 10-20$ ). 
Seperti lazimnya setiap akan dilaksanakannya Pemilihan Umum (pemilu), seluruh perhatian, pikiran, dan energi elit partai politik yang menjadi peserta pemilu, digunakan untuk melakukan berbagai kegiatan kampanye mulai dari bakti sosial untuk mencari simpati dari masyarakat, pengumpulan massa, pemasangan atribut partai hingga membuat iklan politik. Fenomena seperti itu menunjukkan gairah pesta demokrasi yang dilaksanakan selama 5 tahun sekali. Persaingan antar elit partai politik yang banyak bermunculan di era reformasi ini membuat para penggiatnya harus berpikir dua kali lebih keras untuk menawarkan partai dan kadernya kepada calon pemilih. Berbagai upaya telah dilakukan oleh para elit politik untuk mensosialisasikan partai dan kadernya kepada masyarakat dengan harapan masyarakat menaruh simpati kepada partainya (Sosiawan, 2009 :1-5). Salah satunya melalui media daring atau online. Pada akhirnya, internet dan politik memiliki keterkaitan dan memberikan hubungan timbal balik tersendiri. Seperti apa yang digagas oleh Ilmuwan Politik Roelofs, politik merupakan suatu pembicaraan atau lebih tepatnya kegiatan politik adalah bicara. Oleh karena di dalam setiap tindakan politik, selalu ada proses untuk melakukan suatu komunikasi. Hal tersebut merupakan usaha manusia dalam berinteraksi guna memenuhi kebutuhannya. Aktifitas di dunia maya tersebut dapat sedikit menguntungkan para politisi untuk melakukan kampanye secara cuma-cuma dan lebih mudah, hanya saja harus memiliki manajemen komunikasi yang baik. Adanya aktifitas di dunia maya tersebut menjadi suatu alasan tersendiri untuk kalangan politisi menggunakan internet sebagai media kampanye.

\section{Metode Penelitian}

Metode yang dipergunakan dalam penelitian ini adalah metode deskriptif dengan teknik analisis isi. Penelitian deskriptif mempelajari masalah-masalah dalam masyarakat, serta tatacara dalam masyarakat dan situasi-situasi tertentu, termasuk tentang hubungan, kegiatan, sikap, pandangan serta proses-proses yang sedang berlangsung dan pengaruh dari suatu fenomena. Tujuan penelitian deskriptif adalah membuat deskripsi, gambaran, atau lukisan secara sistematis, faktual dan akurat mengenai fakta-fakta, sifat-sifat serta hubungan antara fenomena yang diselidiki (Nazir, 1988 : 63 ).

Teknik penelitian yang digunakan dalam penelitian ini ialah teknik penelitian analisis isi. Teknik analisis isi merupakan teknik penelitian untuk melukiskan isi komunikasi yang nyata secara deskriptif, sistematik, dan kuantitatif. Menurut Krippendorf, analisis isi adalah teknik penelitian untuk membuat inferensiinferensi yang dapat ditiru dan sahih data dengan memperhatikan konteks. Menurut Jalaluddin Rakhmat, analisis isi berguna untuk memperoleh keterangan dari isi 
komunikasi yang disampaikan dalam bentuk lambang (Rakhmat, 1991: 89 ).

Populasi dalam penelitian ini adalah media online yang memberitakan dugaan penghinaan kitab suci Al-Qur'an oleh Cagub Ahok dalam Pilkada DKI semenjak 5 Oktober 2016, sedangkan sampel dari penelitian ini adalah pemberitaan di media Kompas.com, Detik.com, Merdeka.com pada rentang waktu 5 Oktober 2016 s.d. 25 Oktober 2016.

\section{Analisis dan Pembahasan}

Bagian ini akan menjelaskan pemetaan sikap beberapa media daring dengan melihat pada elemen frekuensi pemberitaan, pilihan fokus pemberitaan, pilihan narasumber dan tendensi sikap media terhadap masalah dugaan Cagub Ahok melakukan penghinaan terhadap kitab suci Al-Qur'an. Dari keempat elemen tersebut akan didapatkan sikap masingmasing media terhadap isu dugaan Cagub Ahok melakukan penghinaan terhadap kitab suci Al-Qur'an.
1. Pemetaan Frekuensi Pemberitaan Isu Dugaan Penghinaan Cagub Ahok terhadap Kitab suci Al-Qur'an

Frekuensi pemberitaan akan memperlihatkan sejauh mana media berkepentingan dan mengambil fokus terhadap pemberitaan. Frekuensi pemberitaan juga menunjukkan seberapa kuat isu sehingga memiliki daya tarik bagi proses peliputan berita. Bagi Media, hal itu dilakukan untuk menarik sebanyak mungkin pengunjung untuk melihat beranda beritanya. Isu yang memiliki daya tarik tinggi diperlihatkan dengan antusiasme publik untuk mencari dan mengolah informasi mengenai isu yang dimaksud. Antusiasme publik itulah yang akan menjadi sasaran "pasar" media daring.

Media daring seperti Kompas.com, Detik.com dan Merdeka.com pun dalam meliput isu Pilkada DKI juga melihat kecenderungan yang sedang berkembang, termasuk terkait isu dugaan penghinaan kitab suci Al-Qur'an yang dilakukan Cagub Ahok. Media-media tersebut sekali lagi berusaha mendapatkan antusiasme publik, khususnya para pengguna internet untuk mengakses berita mereka.

Tabel 1. Pemberitaan Beberapa Media Daring terhadap Dugaan Penghinaan Kitab Suci Al-Qur'an yang Dilakukan Cagub Ahok

\begin{tabular}{|l|l|l|}
\hline No & Nama Media & Frekuensi Pemberitaan \\
\hline 1 & Kompas.com & 12 \\
\hline 2 & Merdeka.com & 14 \\
\hline 3 & Detik.com & 7 \\
\hline
\end{tabular}


Berdasarkan pemetaan frekuensi pemberitaan media daring di atas, terlihat bahwa Merdeka.com menjadikan masalah dugaan penghinaan Al-Qur'an oleh Cagub Ahok sebagai isu yang kuat dalam pemberitaannya. Selama rentang waktu 5 Oktober s.d. 20 oktober 2016, Merdeka.com memberitakan masalah dugaan penghinaan Al-Qur'an oleh Cagub Ahok sebanyak 14 kali. Adanya jumlah pemberitaan yang lebih banyak daripada dua media daring lainnya ini memperlihatkan Merdeka.com memang memberikan perhatian serius terhadap isu. Merdeka.com dalam rentang tersebut benar-benar menyoroti isu tersebut dan ini dapat memperlihatkan bagaimana sikap media terhadap isu yang bersangkutan. Merdeka.com fokus pada isu hangat yang sedang berkembang di publik sehingga berusaha menunjukkan perhatian terhadap permasalahan dengan menunjukan pemberitaan yang menyesuaikan aktualitas isu.

Di sisi lain, Detik.com tampaknya tidak terlalu menunjukkan perhatian pada pemberitaan masalah dugaan Cagub Ahok. Detik.com hanya menayangkan pemberitaan terkait masalah dugaan penghinaan Al-Qur'an oleh Cagub Ahok sebanyak 7 Kali. Minimnya perhatian pemberitaan Detik.com terhadap isu yang bersangkutan memperlihatkan bagaimana sikap media menyikapi masalah terkait.

2. Pemetaan Frekuensi Pilihan Fokus yang Diambil Media Daring dalam Memberitakan Dugaan Penghinaan Al-Qur'an oleh Cagub Ahok

Pilihan fokus pemberitaan yang diambil media akan menjelaskan bagaimana sebenarnya perhatian terhadap permasalahan dan cara media dalam membangun kerangka pikir dalam proses peliputan. Pilihan fokus adalah substansi yang berusaha disampaikan media kepada publik. Pilihan fokus pemberitaan memperlihatkan bagaimana sebenarnya tipikal atau konsen permasalahan yang sering diliput oleh media yang bersangkutan. Pilihan fokus pemberitaan akan memperlihatkan karakteristik dari media. Untuk melihat hal tersebut, berikut adalah hasil tabulasi kalkulasi pilihan fokus media daring terhadap masalah dugaan penghinaan Al-Qur'an oleh Cagub Ahok. 
Tabel 2.

Pemetaan Frekuensi Media Daring terhadap Fokus Pemberitaan Masalah Dugaan Penghinaan Al-Qur'an oleh Cagub Ahok

\begin{tabular}{|l|l|l|l|}
\hline Fokus Pemberitaan & Kompas.com & Merdeka.com & Detik.com \\
\hline $\begin{array}{l}\text { Bantahan Cagub Ahok } \\
\text { terhadap Isu }\end{array}$ & 2 & 0 & 3 \\
\hline $\begin{array}{l}\text { Pembelaan Rekan Politik } \\
\text { Cagub Ahok terkait Isu }\end{array}$ & 2 & 0 & 0 \\
\hline $\begin{array}{l}\text { Permintaan Maaf Cagub } \\
\text { Ahok terkait Isu }\end{array}$ & 1 & 1 & 0 \\
\hline $\begin{array}{l}\text { Penegakan Hukum terkait } \\
\text { Isu }\end{array}$ & 7 & 13 & 4 \\
\hline
\end{tabular}

Berdasarkan tabel 2, dapat disimpulkan bahwa fokus pemberitaan yang dominan adalah berkaitan dengan penegakan hukum terkait dengan isu dugaan penghinaan Al-Qur'an oleh Cagub Ahok. Semua media dari yang diteliti sama-sama menjadikan penegakan hukum terkait dugaan penghinaan Al-Qur'an oleh Cagub Ahok sebagai sorotan utama. Kompas.com memberitakan penegakan hukum terkait isu bersangkutan sebanyak 7 kali, Merdeka.com sebanyak 13 kali, dan Detik.com sebanyak 4 kali.

Fokus pemberitaan yang kurang disorot oleh ketiga media daring adalah terkait pembelaan rekan politik Ahok terhadap isu yang bersangkutan. Pada rentang 5 Oktober s.d. 20 Oktober 2016, Kompas.com memberitakan pembelaan rekan politik Ahok terhadap isu yang bersangkutan sebanyak 2 kali. Sementara itu, Merdeka.com dan Detik.com sama sekali tidak menyoroti pemberitaan terkait dengan isu pembelaan rekan politik Cagub
Ahok. Pemilihan fokus pemberitaan dan pilihan peliputan media daring ini jelas memperlihatkan

bagaimana kecenderungan sikap media terhadap permasalahan.

3. Pemetaan Kalkulasi Pilihan Narasumber terhadap Peliputan Masalah Dugaan Penghinaan AlQur'an oleh Cagub Ahok.

Pilihan narasumber yang diambil media akan memperlihatkan bagaimana posisi politis media yang bersangkutan. Media dalam meliput berita tentunya akan mempertimbangkan keuntungankeuntungan politis tertentu. Kedekatan media dengan aktor politik dapat diperlihatkan dari mana sumber berita itu ditulis. Pilihan narasumber juga mempengaruhi keberpihakan, dan lebih jauh mempengaruhi framing media terhadap permasalahan. Oleh karena itu, dalam pemberitaan kasus dugaan penghinaan Al-Qur'an oleh Cagub Ahok, perlu melihat kecenderungan yang muncul 
dalam pilihan narasumber yang diambil beberapa media daring. Hasil analisis bisa dilihat pada tabel 3 .

Tabel 3.

Pilihan Narasumber Media Daring terhadap Pemberitaan Dugaan Penghinaan Al-Qur'an oleh Cagub Ahok.

\begin{tabular}{|l|l|l|l|}
\hline Pilihan Narasumber & Kompas.com & Merdeka.com & Detik.com \\
\hline Cagub Ahok & 3 & 3 & 3 \\
\hline Rekan Politik Cagub Ahok & 3 & 1 & 0 \\
\hline Pemuda Muhammadiyah & 1 & 0 & 0 \\
\hline Nadhatul Ulama & 1 & 0 & 0 \\
\hline MUI & 2 & 2 & 2 \\
\hline Mentri Agama & 0 & 0 & 1 \\
\hline POLRI & 2 & 0 & 0 \\
\hline Masyarakat & 0 & 8 & 1 \\
\hline
\end{tabular}

Tabel 3 menunjukkan bahwa setiap media daring memiliki sikap yang berbeda dalam menentukan narasumber pemberitaan. Dalam hal ini, tiap media dalam memilih narasumbernya memperlihatkan sikap media, yang kemudian akan mencerminkan bagaimana pola perilaku media menyikapi isu yang bersangkutan. Kompas.com memberikan dan mencari narasumber yang berimbang dalam memberitakan masalah dugaan penghinaan Al-Qur'an oleh Cagub Ahok. Kompas.com mengambil narasumber Cagub Ahok sebanyak 3 kali, rekan politik Cagub Ahok sebanyak 3 kali, Pemuda Muhammadiyah sebanyak 1 kali, Nadhatul Ulama sebanyak 1 kali, MUI sebanyak 2 kali, dan POLRI sebanyak 2 kali. Kompas.com hanya tidak mengambil narasumber dari masyarakat dan Menteri Agama.

Merdeka.com, di sisi lain, memperlihatkan pola yang berbeda dalam memberitakan dugaan penghinaan AlQur'an yang dilakukan Cagub Ahok. Merdeka.com nampaknya lebih condong untuk mengambil narasumber dari masyarakat. Sikap Merdeka.com untuk lebih cenderung mengambil narasumber dari masyarakat ini memperlihatkan sudut pandang tertentu media yang bersangkutan. Merdeka.com mengambil narasumber masyarakat sebanyak 8 kali, Cagub Ahok sebanyak 3 kali, dan MUI sebanyak 2 kali.

\section{Tendensi Sikap Media Daring terhadap Pemberitaan Dugaan Penghinaan Al-Qur'an oleh Cagub Ahok}

Kemudian, jika dilihat secara umum kecenderungan media daring dalam meliput masalah dugaan penghinaan Al-Qur'an oleh Cagub Ahok, maka dapat dilihat pada tabel 4.1 dan 4.2. Berdasarkan tabel 4.1. dan 4.2. terlihat bahwa Kompas.com dan Detik.com sama-sama memberikan respon positif terkait bantahan Cagub Ahok 
terhadap Isu penghinaan Al-Qur'an. Dalam

2 kali pemberitaan mengenai bantahan

Cagub Ahok terhadap isu tersebut,

Kompas.com memberikan 2 kali respon positif. Sementara itu, dalam 3 kali pemberitaan mengenai bantahan Cagub Ahok terhadap isu, Detik.com memberikan
3 kali respon positif dalam memberitakan isu tersebut. Di lain sisi, Merdeka.com sama sekali tidak tertarik untuk memberitakan isu tersebut, dan tidak menyatakan sikap terkait hal tersebut.

Tabel 4.1. Pemetaan Tendensi Sikap Media Daring terhadap Dugaan Penghinaan AlQur'an oleh Cagub Ahok dengan Fokus Pemberitaan Bantahan Cagub Ahok terhadap Isu

\begin{tabular}{|l|l|l|l|}
\hline Gambaran & Kompas.com & Merdeka.com & Detik.com \\
\hline $\begin{array}{l}\text { Bantahan Cagub } \\
\text { Ahok terhadap Isu }\end{array}$ & 2 & 0 & 3 \\
\hline Positif & 2 & 0 & 0 \\
\hline Negatif & 0 & 0 & 0 \\
\hline Positif + Negatif & 0 & 0 & 0 \\
\hline $\begin{array}{l}\text { Tidak ada + Tidak } \\
\text { jelas }\end{array}$ & 0 & 0 & 0 \\
\hline
\end{tabular}

Tabel 4.2. Pemetaan Tendensi Sikap Media Daring terhadap Dugaan Penghinaan AlQur'an oleh Cagub Ahok dengan Fokus Pemberitaan Pembelaan Rekan Politik Cagub Ahok terhadap Isu.

\begin{tabular}{|l|l|l|l|}
\hline Gambaran & Kompas.com & Merdeka.com & Detik.com \\
\hline $\begin{array}{l}\text { Pembelaan Rekan Politik } \\
\text { Cagub Ahok terhadap Isu }\end{array}$ & 2 & 0 & 0 \\
\hline Positif & 1 & 0 & 0 \\
\hline Negatif & 0 & 0 & 0 \\
\hline Positif + Negatif & 0 & 0 & 0 \\
\hline Tidak ada + Tidak Jelas & 1 & 0 & 0 \\
\hline
\end{tabular}

Berdasarkan 4.2, di sisi lain, menunjukkan bahwa Merdeka.com dan Detik.com tidak tertarik untuk memberitakan pembelaan rekan politik
Cagub Ahok terhadap isu penghinaan AlQur'an. Sikap Merdeka.com dan Detik.com bisa jadi menggambarkan keengganan dan sikap tak ambil bagian dalam menanggapi 
pemberitaan yang bersangkutan. Di lain sisi, Kompas.com yang memberitakan pembelaan rekan politik Cagub Ahok terhadap isu memberikan respon positif sebanyak satu kali dan ketidakjelasan sikap sebanyak satu kali.

Tabel 4.3. Pemetaan Tendensi Sikap Media Online terhadap dugaan penghinaan Al-Qur'an oleh Cagub Ahok dengan Fokus Pemberitaan Permintaan Maaf Cagub Ahok.

\begin{tabular}{|l|l|l|l|}
\hline Gambaran & Kompas.com & Merdeka.com & Detik.com \\
\hline $\begin{array}{l}\text { Permintaan Maaf Cagub } \\
\text { Ahok terkait Isu }\end{array}$ & 1 & 1 & 0 \\
\hline Positif & 1 & 1 & 0 \\
\hline Negatif & 0 & 0 & 0 \\
\hline Positif + Negatif & 0 & 0 & 0 \\
\hline Tidak ada + Tidak Jelas & 0 & 0 & 0 \\
\hline
\end{tabular}

Tabel 4.3 yang menggambarkan sikap pemberitaan terkait permohonan maaf, tampak bahwa Kompas.com dan Merdeka.com sama-sama memberikan respon positif. Dalam 1 kali pemberitaan mengenai bantahan Cagub Ahok terhadap isu, Kompas.com memberikan 1 kali respon positif. Demikian juga,
Merdeka.com memberikan 1 kali respon positif pula dalam memberitakan permohonan maaf tersebut. Di lain sisi, Detik.com sama sekali tidak tertarik untuk memberitakan dan tidak menyatakan sikap dengan konten pemberitaan tersebut.

Tabel 4.4. Pemetaan Tendensi Sikap Media Daring terhadap Dugaan Penghinaan Al-Qur'an oleh Cagub Ahok dengan Fokus Pemberitaan Penegakan Hukum

\begin{tabular}{|l|l|l|l|}
\hline Gambaran & Kompas.com & Merdeka.com & Detik.com \\
\hline $\begin{array}{l}\text { Penegakan Hukum berkaitan } \\
\text { dengan isu }\end{array}$ & 7 & 13 & 4 \\
\hline Positif & 6 & 5 & 4 \\
\hline Negatif & 0 & 0 & 0 \\
\hline Positif + Negatif & 0 & 3 & 0 \\
\hline Tidak ada + Tidak Jelas & 1 & 5 & 0 \\
\hline
\end{tabular}


Tendensi sikap yang berbeda dalam menampilkan penegakan hukum berkaitan dengan penghinaan Al-Qur'an, terlihat bahwa Kompas.com memberitakan sebanyak 7 kali dengan memberikan respon positif sebanyak 6 kali, dan ketidakjelasan sikap sebanyak 1 kali. Sementara itu, Merdeka.com memberitakan penegakan hukum sebanyak 13 kali dengan memberikan respon positif sebanyak $5 \mathrm{kali}$, respon positif dan negatif secara berimbang sebanyak 3 kali, serta ketidakjelasan sikap sebanyak 5 kali. Detik.com memberitakan penegakan hukum terkait penghinaan AlQur'an sebanyak 4 kali, dan memberikan respon positif pula sebanyak 4 kali.

\section{KESIMPULAN}

Dari studi ini, dapat disimpulkan sebagai berikut;

Dalam analisis isi, pemberitaan dugaan penghinaan kitab suci Al-Qur'an yang dilakukan Cagub Ahok, ada beberapa elemen penting yang akan mempengaruhi tendensi sikap media daring, yaitu frekuensi pemberitaan, pilihan narasumber dan fokus pemberitaan.
Berdasarkan analisis isi, dapat dipetakan bahwasannya ketiga media, yakni Kompas.com, Merdeka.com, dan Detik.com memiliki karakteristik yang berbeda-beda dalam memberitakan dugaan penghinaan Al-Qur'an oleh Cagub Ahok.

Merdeka.com memiliki ketertarikan yang kuat dalam memberitakan dugaan penghinaan AlQur'an oleh Cagub Ahok yang diikuti dengan intensitas pemberitaan yang lebih banyak dibanding dua media lain serta lebih perhatian pada konten tentang penindakan hukum kasus ini. Kompas.com memiliki perhatian sedang dalam memberitakan isu ini diikuti dengan ketertarikan pada semua jenis konten berkaitan dengan isu. Detik.com tampaknya tidak terlalu memberikan perhatian terkait dengan isu ini yang dibuktikan dengan intensitas pemberitaan yang rendah, serta penyikapan yang cenderung mencari aman. 


\section{DAFTAR PUSTAKA}

Alam,Lukis. "Influinasi Media Internet terhadap Proses Pemilu di Indonesia” (Makalah disampaikan pada Seminar Nasional Informatika 2009 (SEMNAS IF 2009) UPN "Veteran" Yogyakarta, 23 Mei 2009).

Hasan, Kamaruddin.” Kajian Netralitas Industri Media Dalam Pemilu 2014”. Jurnal SUWA, Vol. XII No. 1 April 2014. Hlm 1-18.

Nazir, Moh.,Ph.D. Metode Penelitian. Jakarta: Ghalia Indonesia,1983.

Pawito. Pemilihan Umum Legislatif Indonesia 2009 dan Media Massa. Surakarta,UNS Press,2012.
Sosiawan, Edwi Arief S.” Cyber Campaign : Iklan Politik Media On Line Vs Media Konvensional ( Refleksi Pemilu Legislatif 2009 ) (Makalah disampaikan pada Seminar Nasional Informatika 2009 (SEMNAS IF 2009) UPN "Veteran" Yogyakarta, 23 Mei 2009).

Suranto,Hanif;J Judy Ramdojo;P Bambang Wisudo. Kritis Meliput Pemilu. Jakarta : Lembaga Studi Pers dan Pembangunan, 2008.

Susanto, Eko Harry." Media Massa, Keterbukaan Informasi Dan Kekuasaan Negara” ( Makalah ini dipresentasikan pada Seminar Besar Nasional Komunikasi Padang, 26-27 November 2013). 